Jurnal Ilmu Dan Teknologi Kesehatan

Vol 6, No 2, Maret 2019

ISSN: 2338-9095 (Print)

ISSN: 2338-9109 (online)

\title{
Evaluasi Ureum Pada Penyandang Diabetes Melitus dalam Risiko Gagal Ginjal di Bengkulu
}

\author{
Raden Sunita, Heru Laksono \\ Poltekkes Kemenkes Bengkulu \\ Email: zawarasunita@yahoo.co.id
}

\begin{abstract}
Artikel history
Dikirim, Des $27^{\text {th }}, 2018$

Ditinjau, Jan $23^{\text {rd }}, 2019$

Diterima, Feb 26 ${ }^{\text {th }}, 2019$
\end{abstract}

\begin{abstract}
Diabetes mellitus (DM) is a disease characterized by continuous and varied increases in blood sugar (glucose) levels due to a disturbance in the pancreas that cannot produce enough insulin. Increased glucose levels can damage the physiology of the kidneys if they exceed the threshold of kidney. DM patients who are more than 5 years old are recommended for initial screening, one of them is an urea examination. This study was a descriptive cross-sectional study design carried out at the Internal Medicine Police Hospital Dr. M. Yunus Bengkulu with 38 people with DM. Sampling using accidental sampling technique. Ureum level examination was carried out using the AU 680 Beckman Coulter Chemistry Analyzer. Results: abnormal urea levels based on the duration of DM $<5$ years as many as $36 \%$ and $>5$ years $87 \%$. abnormal urea levels based on regular drug consumption ie (62\%) while those taking irregular drugs resulting in abnormal urea levels (50)\%). abnormal urea levels based on the duration of suffering $>5$ years and taking medication regularly amounted to $87 \%$ and normal urea levels amounted to $13 \%$. Evaluation of the level of urea in patients with diabetes that exceeds the normal limit is caused by the duration of suffering from diabetes and taking medication regularly.
\end{abstract}

Keywords: Diabetes Melitus, level of urea, Risk of Kidney Failure

\begin{abstract}
ABSTRAK
Diabetes Melitus (DM) merupakan penyakit yang ditandai dengan meningkatnya kadar gula darah (glukosa) akibat adanya gangguan pada pankreas yang tidak dapat memproduksi hormon insulin dengan cukup. Peningkatan kadar glukosa dapat merusak faal ginjal apabila melewati batas ambang kemampuan ginjal yaitu $160-180 \mathrm{mg} / \mathrm{dL}$. Penderita DM yang lebih dari 5 tahun dianjurkan untuk skrining awal, salah satunya dengan pemeriksaan ureum. Penelitian ini merupakan penelitian deskriptif dengan desain penelitian cross-sectional yang dilakukan di Poli Penyakit Dalam RSUD Dr. M. Yunus Bengkulu dengan populasi 260 orang dan jumlah sampel 38 orang penderita DM. Pengambilan sampel dengan teknik accidental sampling. Pemeriksaan Kadar Ureum dilakukan dengan alat AU 680 Beckman Coulter Chemistry Analyzer. Hasil: kadar ureum abnormal berdasarkan lamanya menderita DM $<5$
\end{abstract}


tahun sebanyak 8 orang $(36 \%)$ dan $>5$ tahun sebanyak 14 orang $(87 \%)$. Kadar ureum abnormal berdasarkan konsumsi obat yang teratur yaitu (62\%) sedangkan yang mengkonsumsi obat tidak teratur hasil kadar ureum nya (50)\%) abnormal. kadar ureum abnormal berdasarkan lamanya menderita $>5$ tahun dan mengkonsumsi obat secara teratur berjumlah 13 orang (87\%) dan kadar ureum normal berjumlah 2 orang (13\%). Evaluasi Kadar ureum penderita DM yang melebihi batas normal disebabkan oleh lamanya menderita DM dan mengkonsumsi obat secara teratur.

Kata kunci: Diabetes Melitus, Ureum, Risiko Gagal Ginjal

\section{PENDAHULUAN}

Diabetes Melitus (DM) merupakan penyakit yang ditandai dengan meningkatnya kadar gula darah (glukosa) secara continue dan bervariasi, terutama setelah makan. Pada saat ini, jumlah usia lanjut ( $\geq 65$ tahun) di dunia diperkirakan mencapai 450 juta orang, sekitar 50\% lansia mengalami intoleransi glukosa dengan kadar gula darah puasa normal. Oleh sebab itu, American Diabetes Association (ADA) menganjurkan skrining DM sebaiknya dilakukan terhadap orang yang berusia 45 tahun ke atas dengan interval 3 tahun sekali (Simanjuntak, 2015).

Diabetes Melitus terjadi dengan adanya gangguan pada pankreas kemudian meningkatkan kadar glukosa, lalu terjadi gangguan metabolisme karbohidrat sehingga karbohidrat tidak dapat menjadi sumber energi secara sempurna, maka lemak dan protein yang menjadi sumber energinya. Sel-sel tubuh juga tidak dapat menyimpan gula dalam bentuk glikogen
(Senthilkumar et al., 2017). Ureum merupakan produk akhir dari metabolisme asam amino, dalam katabolisme protein di pecah menjadi asam amino dan deaminasi ammonia, amonia dalam proses ini disintesis menjadi urea. Reaksi kimia sebagian besar terjadi di hati dan sedikit terjadi di ginjal. Kadar normal ureum adalah 10-40 $\mathrm{mg} / \mathrm{dL}$ dan ureum dieksresikan rata-rata 30 gram sehari (Bhagaskara, Liana, \& Santoso, 2015). Pemeriksaan ureum ini dapat dijadikan sebagai skrining awal Penyakit Ginjal Kronik (PGK). Namun diperlukan waktu 5-10 tahun untuk menjadi masalah kerusakan ginjal (Loho, Rambert, \& Wowor, 2016).

Peningkatan kadar ureum dalam darah selain dengan pertambahan usia dan lamanya menderita DM juga dilihat dari jenis kelamin dan konsumsi obat. Peningkatan ini dilihat dari distribusi lemak tubuh pada laki-laki terjadi penumpukan lemak terkonsentrasi di sekitar perut sehingga mengacu gangguan 
metabolisme, maka kadar ureum pada lakilaki lebih tinggi daripada perempuan (Saryono, 2014). Penderita DM dengan mengkomsumsi obat dalam waktu yang lama dapat meningkatkan kadar ureum sehingga merusak fungsi ginjal (Simanjuntak, 2015).

Diabetes Melitus sudah mencapai proporsi terbanyak di negara berkembang, termasuk di Indonesia. Indonesia memiliki tingkat prevalensi DM tertinggi ke empat setelah India, Cina dan Amerika Serikat. Berdasarkan pola pertambahan penduduk, diperkirakan pada tahun 2030 nanti akan ada 194 juta penduduk yang berusia di atas 20 tahun dengan asumsi prevalensi diperkirakan 12 juta penyandang diabetes di daerah urban dan 8,1 juta di daerah rural (Riskesdas, 2007).

Berdasarkan data dari Dinas Kesehatan Provinsi Bengkulu penderita penyakit DM di Kota Bengkulu pada tahun 2016 mencapai 3.769 kasus DM dengan tingkat kematian 21 orang. Data morbiditas pasien DM Rawat Jalan RSUD Dr. M. Yunus Bengkulu tahun 2016 dengan jumlah kunjungan sebanyak 596 orang. Kadar ureum pada penderita DM di Indonesia sebanyak 18 juta meningkat sekitar $8 \%$ setiap tahunnya. Berdasarkan latar belakang tersebut maka penulis menganalisa Profil Kadar Ureum Penderita Diabetes Melitus (DM) di Poli Penyakit Dalam RSUD Dr. M. Yunus Bengkulu Tahun 2018.

\section{METODE}

Penelitian ini merupakan penelitian deskriptif dengan desain penelitian crosssectional. Populasi penelitian ini adalah penderita DM di Poli Penyakit Dalam RSUD Dr. M. Yunus Bengkulu tahun 2017. Jumlah sampel dalam penelitian ini berjumlah 38 orang dengan teknik accidental sampling (Notoadmojo, 2010). Analisis data yang dilakukan yaitu secara deskriptif, dengan mengetahui kadar ureum pada penderita Diabetes Melitus. Hasil pemeriksaan di Laboratorium dalam bentuk tabel dan dinarasikan kemudian dibuat pembahasan serta ditarik kesimpulan.

\section{HASIL DAN PEMBAHASAN}

Hasil kadar ureum pada penderita DM disajikan pada tabel 1 dan tabel 2 . 
127 Jurnal Ilmu Teknologi Kesehatan, Vol. 6, Nomor 2, Maret 2019, hlm:124-130

Tabel 1. Hasil Kadar Ureum Berdasarkan Lama Menderita DM

\begin{tabular}{ccccccc}
\hline \multirow{2}{*}{$\begin{array}{c}\text { Lama } \\
\text { menderita }\end{array}$} & \multicolumn{2}{c}{ Normal } & \multicolumn{2}{c}{ Abnormal } & \multicolumn{3}{c}{ Total } \\
\cline { 2 - 7 }$<5$ tahun & 14 & $(64 \%)$ & 8 & $(36 \%)$ & 22 & $(100 \%)$ \\
$>5$ tahun & 2 & $(13 \%)$ & 14 & $(87 \%)$ & 16 & $(100 \%)$ \\
\hline Total & & & & & 38 & $(100 \%)$ \\
\hline
\end{tabular}

Pada tabel 1 hasil kadar ureum abnormal berdasarkan lamanya menderita $\mathrm{DM}<5$ tahun sebanyak 8 orang $(36 \%)$ dan $>5$ tahun sebanyak 14 orang $(87 \%)$. Faktor risiko meningkatnya kadar ureum secara signifikan setelah usia 45 tahun dan meningkat secara drastis setelah usia 65 tahun. Pada saat ini, jumlah usia lanjut ( $\geq 65$ tahun) di dunia diperkirakan mencapai 450 juta orang, sekitar 50\% lansia mengalami intoleransi glukosa dengan kadar gula darah puasa normal. Pada usia 75 tahun, diperkirakan sekitar 20\% lansia mengalami DM dan sebagian besar tidak menyadari adanya penyakit ini. Oleh sebab itu, American Diabetes Association (ADA) menganjurkan skrining DM sebaiknya dilakukan terhadap orang yang berusia 45 tahun ke atas dengan interval 3 tahun sekali (Simanjuntak, 2015).

Menurut peneliti lain hasil kadar ureum dapat bertambah dengan bertambahnya usia, walaupun tanpa riwayat penyakit ginjal (Bhagaskara et al., 2015). Penelitian ini juga sejalan dengan penelitian Kurniawan (2015) dengan hasil 50\% pasien DM tipe 2 berusia $>65$ tahun kadar ureumnya meningkat. Sehingga pada usia ini diperlukan pendekatan terapi. Beberapa bukti menyebutkan bahwa kontrol gula darah optimal dan modifikasi faktor risiko dapat mengurangi terjadinya komplikasi pada pasien usia lanjut (Loho et al., 2016).

Lama menderita DM sebagai salah satu faktor risiko meningkatnya kadar ureum. Apabila terjadi penumpukan gula di dalam darah maka kadar ureum akan meningkat akibat adanya kerusakan pada ginjal. Pemeriksaan ureum ini dapat dijadikan sebagai skrining awal Penyakit Ginjal Kronik (PGK). Namun diperlukan waktu 5-10 tahun untuk menjadi masalah kerusakan ginjal (Loho, Rambert, \& Wowor, 2016). 
lama menderita 5-10 tahun dapat

Selain itu, kaum lansia juga mengalami masalah khusus yang memerlukan perhatian, antara lain lebih rentan terhadap komplikasi makrovaskular maupun mikrovaskular dari DM dan adanya sindrom geriatri, biasanya hal ini terjadi pada penderita DM yang lebih dari 5 tahun (Kurniawan, 2015). Sekitar 20\% pasien DM tipe 2 dengan terkena nefropati diabetik dan sekitar $34-45 \%$ pasien dengan DM tipe 1 dengan lama menderita 15-20 tahun ditemukan memiliki penyakit nefropati diabetik (Yoga, 2011). Pada penelitian ini penderita $\mathrm{DM}>5$ tahun dengan kadar ureum abnormal sebanyak 14 orang $(87 \%)$.

Tabel 2 Hasil Kadar Ureum Berdasarkan Konsumsi Obat

\begin{tabular}{|c|c|c|c|c|c|c|}
\hline \multirow{2}{*}{$\begin{array}{c}\text { Konsumsi } \\
\text { obat }\end{array}$} & \multicolumn{6}{|c|}{ Kadar Ureum } \\
\hline & \multicolumn{2}{|c|}{ Normal } & \multicolumn{2}{|c|}{ Abnormal } & \multicolumn{2}{|c|}{ Total } \\
\hline Teratur & 10 & $(38 \%)$ & 16 & $(62 \%)$ & 26 & $(100 \%)$ \\
\hline $\begin{array}{l}\text { Tidak } \\
\text { teratur }\end{array}$ & 6 & $(50 \%)$ & 6 & $(50 \%)$ & 12 & $(100 \%)$ \\
\hline Total & & & & & 38 & $(100 \%)$ \\
\hline
\end{tabular}

Pada tabel 2 hasil kadar ureum abnormal berdasarkan konsumsi obat yang teratur yaitu (62\%) sedangkan yang mengkonsumsi obat tidak teratur hasil kadar ureum nya (50)\%) abnormal. Faktor lain yang menyebabkan kadar ureum meningkat yaitu konsumsi obat. Berdasarkan penelitian ini hasil kadar ureum abnormal bagi penderita DM yang teratur konsumsi obat yaitu 16 orang $(62 \%)$ dan kadar ureum abnormal yang tidak teratur mengkonsumsi obat yaitu 6 orang (50\%). Menurut hasil penelitian sebelumnya pada tahun 2015 hasil kadar ureum sebanyak 50\% meningkat dan 50\% normal. Peningkatan ureum disebabkan oleh penderita DM harus mengkomsumsi obat dalam waktu lama dan tidak mengkonsumsi obat sesuai dengan anjuran dokter, sehingga merusak fungsi ginjal. Namun diperlukan waktu 5-10 tahun untuk menjadi masalah kerusakan ginjal. Sedangkan kadar ureum yang normal pada penderita DM menunjukkan belum adanya komplikasi dengan penyakit lain, dan tidak harus mengkomsumsi berbagai macam obat sehingga fungsi ginjal tidak dirusak (Simanjuntak, 2015). 
Tabel 3 Hasil Kadar Ureum Berdasarkan Lama menderita $>5$ tahun dan Mengkonsumsi Obat Secara Teratur

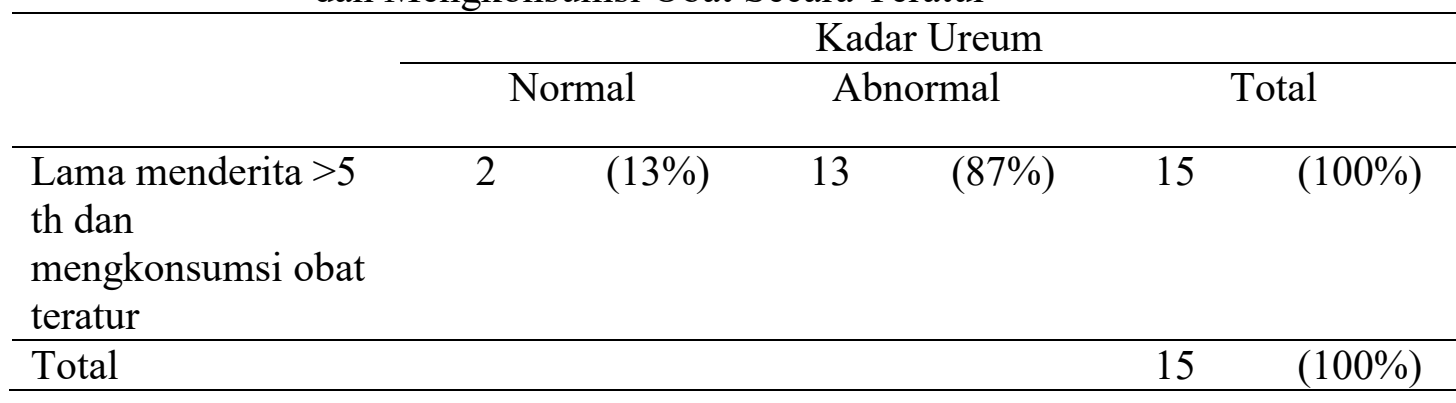

Pada tabel 3 hasil kadar ureum abnormal berdasarkan lamanya menderita $>5$ tahun dan mengkonsumsi obat secara teratur berjumlah 13 orang $(87 \%)$ dan kadar ureum normal berjumlah 2 orang (13\%). Dalam sebuah jurnal Clinical Diabetes yang diterbitkan pada tahun 2012, menyatakan bahwa obat metformin adalah obat yang digunakan untuk menurunkan kadar HbA1C sebanyak 1$2 \%$ dan jumlah gula darah yang masuk ke dalam aliran darah. Jumlah $\mathrm{HbA} 1 \mathrm{C}$ yang normal adalah $<7 \%$. Berbeda dengan obat lain, metformin tidak menyebabkan kenaikan berat badan, karena itu obat ini biasanya diberikan untuk penderita yang mengalami kelebihan berat badan atau obesitas. Tetapi metformin kadang-kadang dapat menyebabkan efek samping yang ringan, misalnya mual dan diare.

Pada penelitian ini yang mengkonsumsi obat metformin dengan kadar ureum abnormal berjumlah 16 orang (61\%) dan kadar ureum normal berjumlah 10 orang (39\%). Jika obat yang dianjurkan dokter tidak dikonsumsi sesuai dengan anjurannya, maka dalam waktu 5-10 tahun akan muncul komplikasi DM. Salah satu komplikasi yang terjadi yaitu dengan peningkatan kadar ureum akibat kerusakan ginjal.

\section{SIMPULAN}

Dari hasil penelitian yang dilakukan pada 38 sampel terhadap pasien penderita Diabetes Melitus di Poli Penyakit Dalam RSUD Dr. M. Yunus Bengkulu, maka dapat diperoleh kesimpulan sebagai berikut :

1. Hasil kadar ureum abnormal penderita DM paling banyak terjadi setelah menderita $\mathrm{DM}>5$ tahun.

2. Hasil kadar ureum abnormal penderita DM paling banyak terjadi pada penderita yang mengkonsumsi obat secara teratur. 


\section{DAFTAR RUJUKAN}

Bhagaskara, Liana, P., \& Santoso, B. 2015. Hubungan Kadar Lipid dengan Kadar Ureum \& Kreatinin Pasien Penyakit Ginjal Kronik di RSUP Dr. Mohammad Hoesin Palembang. Kedokteran Dan Kesehatan, 2(2), 223-230.

Kurniawan, S., \& Fajariati, D. N. 2015. Penentuan Urea Dalam Serum Darah dengan Biosensor Konduktometri Screen Printed Carbon Electrode (SPCE) - Nata De Coco. Molekul, 10(2), 97.

Loho, I. K. A., Rambert, G. I., \& Wowor, M. F. (2016). Gambaran Kadar Ureum Serum pada Pasien Penyakit Ginjal Kronik Stadium 5 Non Dialisis. Jurnal E-Biomedik, 4, 2-7.

Notoadmojo. 2010. Metodologi Penelitian Kesehatan. Jakarta: Rineka Cipta.

Riskesdas. 2007. Riset Kesehatan Dasar (RISKESDAS) Provinsi Bengkulu Tahun 2007. Laporan Nasional 2007. Bengkulu.

Sartika, R. W. 2014. Pemeriksaan Kadar Ureum Dalam Darah Pada Penderita Diabetes Mellitus Yang Dirawat Inap Di Rumah Sakit Estomihi Medan
Tahun 2014. Ilmu Kesehatan. Medan.

Saryono, H. 2014. Kadar Ureum dan Kreatinin Darah Pada Pasien Yang Menjalani Terapi Hemodialisis di Rumah Sakit Umum Margono Soekarjo Purwokerto. Kedokteran Dan Kesehatan, 36-42. Purwokerto.

Senthilkumar, G. P., Anithalekshmi, M. S., Yasir, M., Parameswaran, S., Packirisamy, R. muthu, \& Bobby, Z. 2017. Role of omentin 1 and IL-6 in type 2 diabetes mellitus patients with diabetic nephropathy. Diabetes \& Metabolic Syndrome: Clinical Research \& Reviews, 8-11.

Simanjuntak, F. M. O. 2015. Pemeriksaan Kadar Ureum Pada Penderita Diabetes Melitus Umur 55-65 Tahun diRSU Sari Mutiara Medan Tahun 2015. Kedokteran dan Kesehatan. Medan.

Yoga,S 2011. Hubungan antara 4 pilar pengelolaan Diabetes Melitis dengan keberhasilan pengelolaan DM Tipe 2. Jurnal Kedokteran. Fakultas Kedokteran Universitas Diponegoro.

Zakiah, Z. 2015. Indonesian Kidney Care $C l u b$. Indonesian Journal of Clinical Pathology and Medical Laboratory. 